\title{
砂防ダム方式渓流取水エについて
}

\author{
張 興奇 ${ }^{1} \cdot$ 秋吉康弘 ${ }^{2} \cdot{\text { 行武 } \quad \text { 潔 }^{3} \cdot \text { 渡辺高史 }}^{4}$
}

\section{A Hybrid Structure for Streambed Intake and Debris Storage in Torrents}

\author{
Xingqi Zhang ${ }^{1}$, Yasuhiro Akiyoshi ${ }^{2}$, Kiyoshi Yukitake ${ }^{3}$ and Takashi Watanabe ${ }^{4}$
}

\begin{abstract}
This paper is associated with development of a hybrid structure in torrents that serves for streambed water intake as well as debris storage or erosion control dam. Focusing on the intake structure that comprises trashracks(i.e., bar screens) for removal of impurities such as boulders and dead leaves, and sloped deflector or upright stoplog for enhancement of return flow in a water cushion, its hydraulic. properties were experimentally investigated in terms of the quantity of water abstracted from the incoming debris flow. The variable factors considered are length, slope and clearance of the bar, location and height of the deflector, and location of the stoplog. The results show that the flow rate abstracted from the stream depends heavily on the bar slope, and then the slope of $50^{\circ}$ is most suitable for preventing the impurities from jamming between the bars. Additionally it is demonstrated that the intake flow rate is more effectively increased by an appropriately located stoplog rather than by the deflector, differing from a conventional sole structure for streambed intake.
\end{abstract}

\section{1 はじめに}

近年, 水需要の増加に伴い水資源開発が重要な課題 となっている。しかし, 従来のように河川本流をせ き止めて，ダムを建設する取水方法(on-stream dam) は, ダムが集水と取水機能及び貯水機能とを併せ持 つ方式で，これ自体は利水上有効な方法である。し かし, ダム湖内への土砂碟流入による堆砂問題や, ダム下流側河川では, 土砂砅の供給が停止するため に，河床の侵食等の問題を引き起こしている．また， ダム建設に適する河川地形, 地質, あるいは社会的 条件, 環境保護の面などから, 河川本流へのダム建 設は非常に難しくなっている[1].

このような場合, 渓流河川の地形や地質, 周辺の 状態によっては, 集水と取水機能及び貯水機能とを 分離して持つ（off-stream dam）渓流取水工と貯水池 とからなる利水システムが有利になる場合が多い.

そこで，現在このような off-stream dam の方式を 確立するために渓流取水工の開発が盛んに行われ ている.この渓流取水工は，一般に河床勾配が急で 流量の増減が激しく, 多量の土砂・石碟が流下する 河床変動の激しい所に設置され, 流木・枯葉等の浮 遊流下物が多いため, 設計には, 土砂碟による破壊 に充分注意しながら, 土砂碟及び浮遊流下物と水と を分離し，水のみを取水する構造（土砂砅は若干混 入するが, 取水後沈砂池にて水と土砂砂とを分離す る）でなければならない。

また屋久島や三重用水での取水施設を調査した 結果, 渓流取水工は, 砂防ダムの直下流部に位置し ており，2つの構造物の間隔は約 10 数メートル程 度である。このように2つの構造物が接近して建設

\footnotetext{
${ }^{1}$ 鹿児島大学大学院連合農学研究科博士課程 Doctoral Student, The United Graduate School of Agricultural Science, Kagoshima University, 121-24 Korimoto, Kagoshima, 889-0065 Japan

2 宮㥓大学農学部助教授 Associate Professor, Faculty of Agriculture, Miyazaki University,1-1 Gakuen Kibanadai Nishi, Miyazaki, 8892192 Japan

3 宮崎大学農学部教授 Professor, Faculty of Agriculture, Miyazaki University, 1-1 Gakuen Kibanadai Nishi, Miyazaki, 889-2192 Japan.

4 宮崎大学農学部大学院修士課程 Graduate Student, Graduate School of Faculty of Agriculture, Miyazaki University, 1-1 Gakuen Kibanadai Nishi, Miyazaki, 889-2192 Japan
}

される理由として考えられることは, 施工個所が適 していること, 工事をする上で工事用道路があり工 事費的に軽減できることなどが考えられる.また， 砂防ダムによって土砂碩の流下を防ぎ, 取水工に土 砂砂を直撃させないような考え方が㗢いていると も考えられる。

しかし，2つの構造物が隣接して建設されること は，工事費的に多大な出費となると考える.

そこで, 本研究では, 砂防ダムと渓流取水工とを 合体化させ, 取水と砂防の機能を併せ持つ砂防ダム 方式渓流取水工[2]の新しい構造物を開発すること を目的としている.

\section{2 新しい權造物の設計}

砂防ダムは, 土砂碟の流下を防止するものであり， 取水は本来行われない構造である.しかし, 砂防ダ ムにて取水しようとする場合, ダム上流側に取水塔 や多孔管を設置して取水されている. この場合, 洪
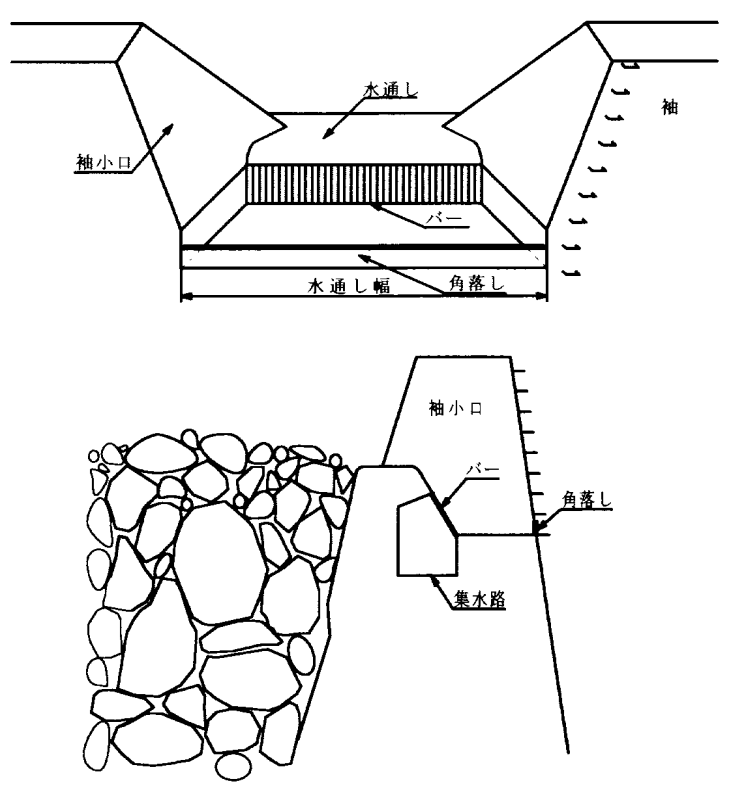

図 1：砂防堰堤と渓流取水工の合体模式図 
水時の土石流による取水施設の破壊が考えられる.

そこで，著者らは，図 1 に示すような砂防ダム放 水路裏面部にバースクリーン型渓流取水工を設置 する構造を考えた。 土石流とは，水と土石からなる 混合流であるため, 流水の掃流力によって押し流さ れる[3,4]. 巨石も浮力で容易に移動すると考えられ る.そこで，土石流中の水を渓流取水工にて除去す れば, 流水によって押し流される土石の流下を減少 させ，士石流による河川下流の災害防止が可能と考 えた. 平水時には, 通常どおり渓流取水工として用 水を取水することができ一石二鳥と考える.また，

$2 つ$ 構造物を合体化させることによって工事費 の軽減も可能と考える.

そこで，本報では，砂防ダム方式渓流取水工の合 理的な構造を明らかにするために, バースクリーン の取付角度，長さ，開度や，デフレクター（水クッ ション下流端に設置）の斜面傾斜度，及び這い上が り高さ, 水クッション底床部水平長等の要因を変化 させて模型実験を行い，特にこれら要因の組み合わ せによる取水特性を比較検討し究明するものであ る.

\section{3 実験装置及び実験方法}

実験装置は，幅 $0.40 \mathrm{~m}$, 哚さ $0.52 \mathrm{~m}$ の幹線水路末端 部に設置された写真 1 及び図 2 に示す構造である. 越流堰は，高さ $0.12 \mathrm{~m}$ で，曲率半径約 $0.125 \mathrm{~m}$ であ り，バー直径 $(\phi)$ は $0.018 \mathrm{~m}$ ，バー間隙幅 $(a)$ は $0.01 \mathrm{~m}$ と $0.02 \mathrm{~m}$ の 2 段階に, バー長 $(L)$ は $0.25 \mathrm{~m}, 0.30 \mathrm{~m}$, $0.40 \mathrm{~m}$ の 3 段階に，バ一取付角度 $\left(\theta_{1}\right)$ は $40^{\circ}, 45^{\circ}$, $50^{\circ}, 60^{\circ}$ の 4 段階である。バー末端部からのエプロ ン長は $0.70 \mathrm{~m}$ である.デフレクターの諸元は, 高さ

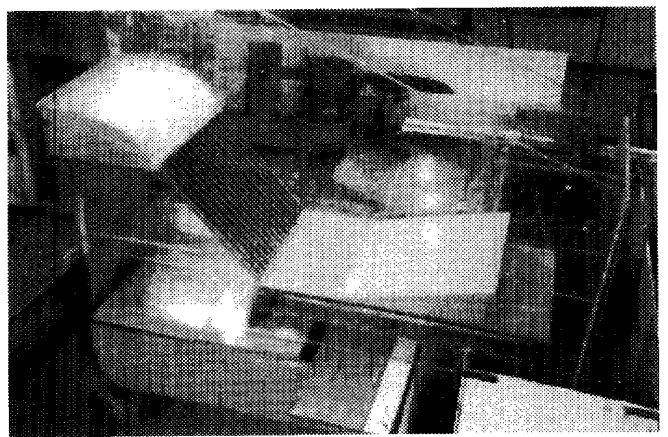

写真 1：実験装置写真

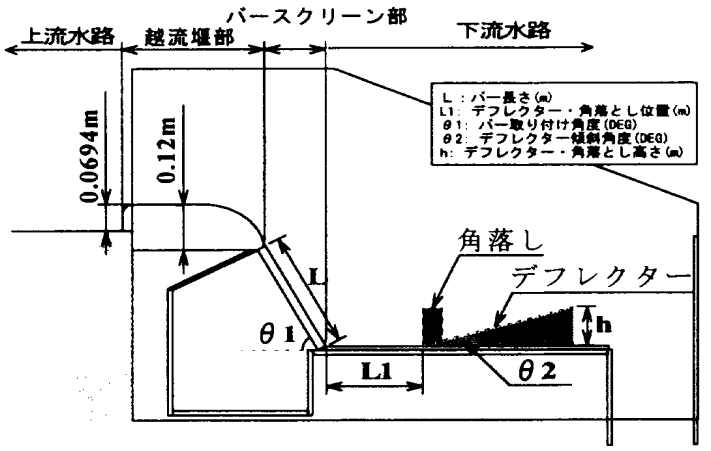

図 2: 実験装置概略図 (h) $0.10 \mathrm{~m}$ の時, 傾斜度 $\left(\theta_{2}\right)$ は $15^{\circ}$ で, 高さ $(h) 0.15 \mathrm{~m}$ の時，傾斜度 $\left(\theta_{2}\right)$ は $22^{\circ}$ の 2 段階である.また， デ フレクター設置位置, すなわち, 水クッション底床 部水平長 $\left(L_{1}\right)$ はバ一下端部から $0 \mathrm{~m}, 0.036 \mathrm{~m}, 0.136 \mathrm{~m}$, $0.236 \mathrm{~m}, 0.336 \mathrm{~m}$ の 5 段階に変化させた. また,角落 しの場合は, 高さ $0.10 \mathrm{~m}$ で, 角落し設置位置の水ク ッション底床部水平長 $\left(L_{1}\right)$ は $0.236 \mathrm{~m}, 0.436 \mathrm{~m}$, $0.636 \mathrm{~m}$ の 3 段階に変化させて実験を行い, 流況と 取水量について検討した。

実験方法は，まず，幹線水路上流部に位置する四 角堰付きの量水槽で流量を計量し流下させ,バース クリーン型渓流取水工にて取水された取水量を量 水槽で計量する.水深はポイントゲージにて測定し， 流況は，写真撮影によって観察した。幹線水路の流 量は, $5 \mathrm{\ell} / \mathrm{s}$ 間隔に 80 l/s まで 16 段階で実験した。 本来,渓流取水工は，土砂碩をあまり混入させな いで用水のみを取水することを目的としているた めに，バースクリーン開度は，8\%～35\%前後の值を 採用しているが, 本砂防ダムに設置する渓流取水工 の場合には，少々の土砂碩の混入も生じるが，でき るだけ取水量を多くすることを目的として，バース クリーン開度を $55 \%$ 程度と大きく計画した。

\section{4 実験結果及び考察}

バースクリーン型渓流取水工の取水量は,バースク リーンの諸元と集水路断面の大きさから規定され るが，本研究では，バースクリーンにて取水される 最大量を求めるために, 集水路断面積を十分確保し, バースクリーンの諸元を変化させながら, 取水量と 流況の変化を比較検討した。

\section{1 バ一長とバ一取付角度の变化による取水量}

バー長と取付角度を変化させた場合の取水量の変 化量を図 3 に示す. 図 3 は, 水クッション内にデフ レクターを設置せず，バ一間隙幅を $0.02 \mathrm{~m}$ とし，バ 一長を $0.25 \mathrm{~m}, 0.30 \mathrm{~m}, 0.40 \mathrm{~m}$ ，バー取付角度を $40^{\circ}$ ， $50^{\circ}$ と $60^{\circ}$ に変化させた場合の取水量を比較したも のである。

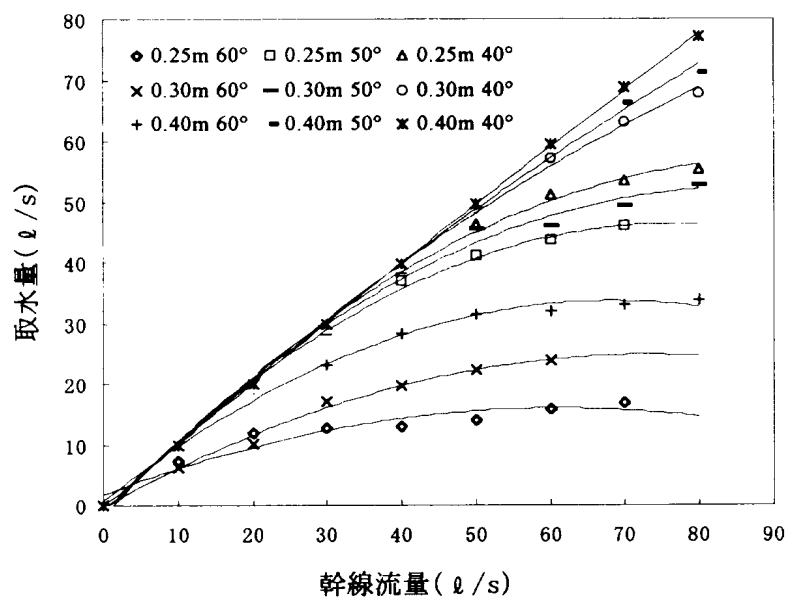

図 3: 取水量と幹線流量との関係

この結果, バ一長が同じ場合, バー取付角度が小 
さくなればなるほど取水量は増加する傾向にある. しかし, バー取付角度が $60^{\circ}$ の場合の取水量を, $40^{\circ}$ と $50^{\circ}$ の場合と比較すると，極端に小さくなる。一 方, バー取付角度が同一の場合, バー長は長くなれ ばなるほど取水量は増加する傾向を示したが，その 増加量は小さい，実験では，バ一長 $0.40 \mathrm{~m}$, 取付角 度 $60^{\circ}$ の場合よりバー長 $0.25 \mathrm{~m}$, 取付角度 $50^{\circ}$ の方 が取水量は増加する結果が得られた。よって, 取水 量はバー取付角度に大きく影響されることを確認 した。しかし，バ一取付角度をあまり小さくすると， 枯れ葉や土砂碩などがバースクリーンに引っかか り易くなり目詰まりを生じ, 逆に取水量は低下寸る。 そのため, バースクリーンの取付角度は, 取水量や 渓流の流況などを考慮し， $40^{\circ} \sim 50^{\circ}$ が適当であると 思われる. 新しい構造物では土砂䂰の流下が多いた め，50とすることが最良であると考える。

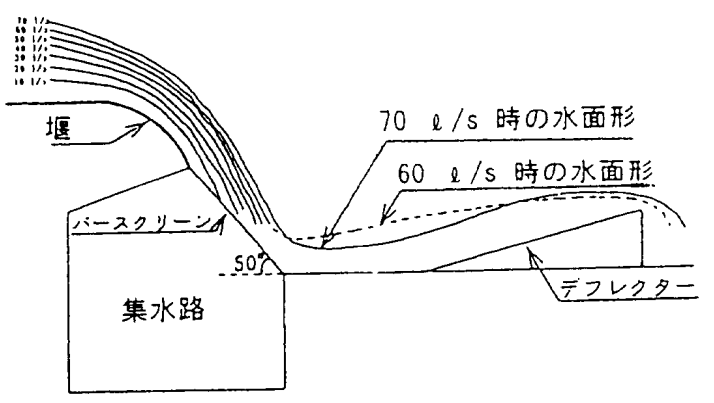

図 4: 越流ナップの表側の形状

つぎに,バースクリーン上を流下するナップの形 状とバー取付角度の変化に伴う流況の関係を実験 的に観察した。1例ではあるバー長 $0.25 \mathrm{~m}$ で流量を $10 \mathrm{\ell} / \mathrm{s}$ 間隔に $70 \mathrm{\ell} / \mathrm{s}$ まで7段階流した時の流況を図 4 に示す.

ナップの形状は越流堰の形状に影響されるがほ ぼ放物線を描きながら落下する。 そこで，バーが設 置されてない場合や, バ一取付角度が極端に大きい $\left(70^{\circ} \sim 90^{\circ}\right)$ 場合, ナップはバースクリーンと接触 することなしにバーの上部を飛ぶように流下し, 流 水は下流へ流去する。しかし，バ一取付角度が小さ くなるとナップはバースクリーン上端を沿うよう に流れ，小流量の場合,流水はバーを巻き込むよう にバー間隙から下部へ落下する。この場合が全量取 水時の流況である. さらに, 流量が増大してくると 流水はバースクリーンを覆うようにバースクリー ン幅全体を流れ，バー間隙から多くの流水が落下す ると同時にバー上をも流れ下流に流去する. そして， バ一間隙から落下しきれない流水が下流に流去し, ナップは水クッション内の流水と連続する流況を 呈する.このような流況が部分取水である.また， バー長が長くなるとバーの水平距離はナップの飛 距離よりも長くなるために流下水は全てバー間隙 を通過して全量取水の流況を呈するようになる.

そこで, 前述の図 3 で得られたようなバ一取付角 度が $60^{\circ}$ の時と $50^{\circ}, 40^{\circ}$ の時との取水量の極端な違
いは，バー取付角度が $60^{\circ}$ の時はバーとナップとの 接触が少なく $50^{\circ}, 40^{\circ}$ のようにバー取付角度が小 さくなる時に比較してバ一間隙から落下寸る取水 量は極端に少なくなるものと考えられる.このよう に取水量はナップの形状とバー長, 及びバー取付角 度に大きく影響することが考えられる。

また, ナップ形状は, 越流堰の形状に影響され, 従来の設計では, ナップの曲率半径は段落斜面高 $W$ の $1 / 5$ 程度とされている[2].

バー長については, バー長が長くなればなるほど 取水量は増大寸るが，土砂碩の衝突に対する強度が 低下するため, 渓流の土砂碎の大きさや, 粒径など に応じて決定する必要がある. 従来, バーの材料は 鋼管が使用されてきたが，近年鋼棒を使用するよう になった. 鋼棒の使用は,バースクリーンの開度を 大きくすることができ，その分バー長を短くするこ とが可能となり, バーの強度の増加に有効となる。

\section{2 デフレクターと角落しによる取水状況の比較}

バースクリーン型渓流取水工における取水状況は, 流下流量が増大してくると,バースクリーンの上を 通過する水流の一部はバーの末端部から流去し始 めるが, これら流去する水量までも取水するために は, 水クッション内にデフレクターや角落しを設置 する必要がある.

デフレクタ一や角落しを設置した場合, たとえば, バー長 $0.30 \mathrm{~m}$, 取付角度 $50^{\circ}$, デフレクター高 $0.10 \mathrm{~m}$, 水平長 $0.136 \mathrm{~m}$ のときの流況は, 図 5 に示すように, 流下流量が少ない場合には, 全量取水の傾向を示す. しかし, 流下流量が増大してくると, 前述のように バーの上を越流して下流に流去する流量が多くな り, 逆に取水量が減少し始め, 取水量の増加率は低 下傾向を示す.この時点でいままで常流状態であっ た水クッション内の流況は, 射流状態となり, 露出 射流を形成する. 一旦射流状態が形成されると, さ らに流下流量が増大しても, 取水量の増加は少なく

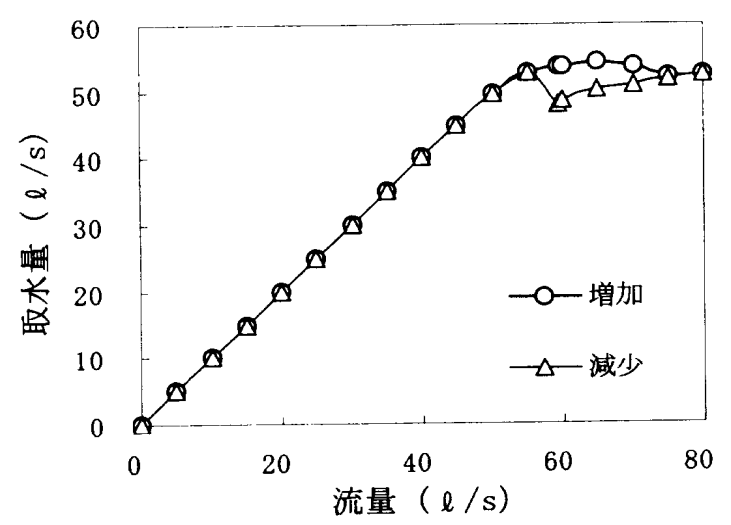

図 5: 取水量の変化及び履歴現象

なり，取水量はほぼ一定化するようになる. その後, 洪水のピークが過ぎ, 流下流量が減少し始めると, 水クッション内の流況は, 再び, 射流状態から常流 状態に変化する. しかし, 流下流量の増加時におけ る常流状態から射流状態へ移行するときの流量と， 
逆に減少時の射流状態から常流状態に移行すると きの流量とは異なり履歴現象が生じる. その結果, 取水量にも変化が生じることとなる.しかし，この ような履歴現象は, 土石流の発生を想定するとき, 水クッション内の土砂䃇排除のためには非常に有 利な現象である。すなわち，土石流のピーク後に土 砂䃇の堆積が生じやすくなる現象を考えると, 土石 流のピークを過ぎても射流状態が持続しているこ とは, 水クッション内の土砂碟が露出射流によって 除去され清掃されることになる。しかし，角落しの 場合は，水クッション内の流況は，射流状態にはな りにくく，流量が増大寸ると，流水は激しい勢いで 角落しに衝突して, 上向きの流況を呈しながら流去 する。

いま, 水クッション底床部にデフレクターを設置 する場合と設置しない場合及び角落しを設置する 場の取水量変化状況を図 6 に示す。

デフレクターの設置位置は，バーの末端部から $0 \mathrm{~m}, 0.036 \mathrm{~m}, 0.136 \mathrm{~m}, 0.236 \mathrm{~m}, 0.336 \mathrm{~m}$ の 5 段階に 変化させたが, 図 6では $0.136 \mathrm{~m}$ と $0.336 \mathrm{~m}$ の二段階 の結果を示す．角落しの高さは $0.10 \mathrm{~m}$, 設置位置は バーの末端部から $0.236 \mathrm{~m}, 0.436 \mathrm{~m}, 0.636 \mathrm{~m}$ の三段 階である。

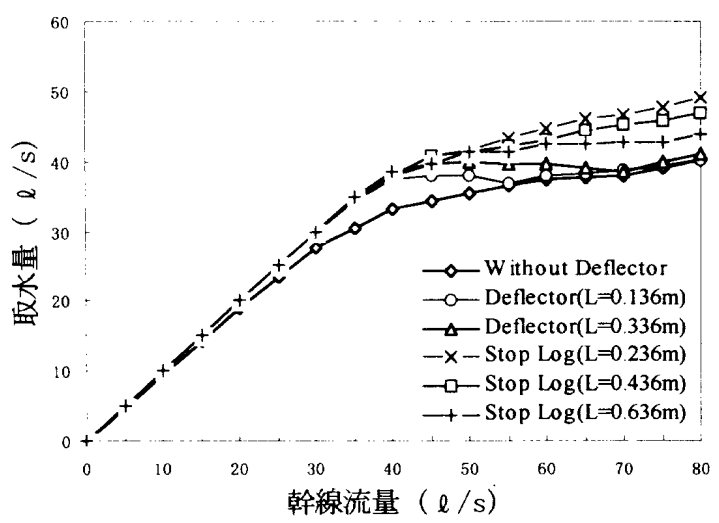

図 6: デフレクターと角落しによる取水量の変化

\subsection{1 デフレクタ一設置位置による取水量の变化} デフレクターを設膡する場合, 流下流量が少ない時 には, 水クッション内の流況は常流状態を呈するた め,バースクリーン隙間からの下方流入水に加えて 水クッションからの後方流入水が流入し, 水クッシ ヨンのない場合より取水量は増大する。しかし，流 下流量がある水量以上に達すると水クッション内 の流況は，露出射流を形成する。乙して，取水量は， デフレクターを設置しない場合と同一の取水量の 変化を呈するようになる。

図 6 での取水量変化曲線の凹んだところが露出 射流が発生した地点である。露出射流の発生は，バ 一の取付角度が大きくなればなるほど, 水クッショ ン底床部水平長が短いほど，また，デフレクターの 這い上がり高が低いほど発生しやすくなる。

いま, これらの現象のうち, 水平長の長短の違い による流況変化を示すと, 写真 2 , 写真 3 の通りで ある. 写真 2 は、デフレクターをバ一末端に近付け
た場合すなわち，水平長が短い場合であり，少ない 幹線流量によって, 水クッション内の流況は, 露出 射流を生じやすくなる，そのためにバースクリーン からの取水量は減少する.しかし, 写真 3 のように,

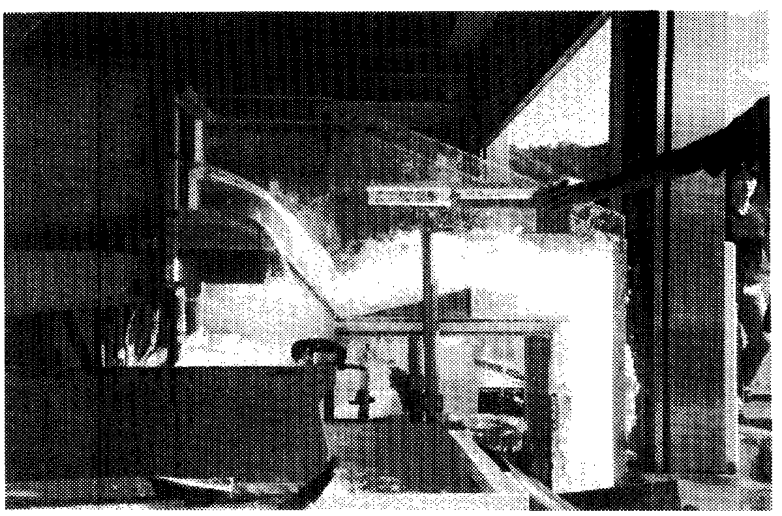

写真 2: デフレクター前方設置時の流況

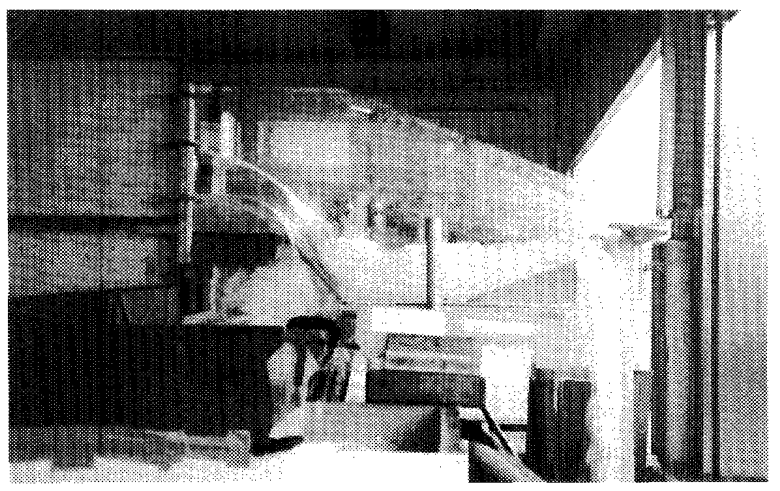

写真 3: デフレクター後方設置時の流況

水クッション内の水平長が長くなると，短い場合 と同じ流下流量においても水クッション内の流況 は, 常流状態を維持しつづけ後方流入水が多くなり， 取水量は增加する。

また, 取水量の変化は, 図 6 のように流下流量の 増大にしたがって取水量は増加するが, 流下流量が ある量に達すると取水量は増加しなくなり，ほぼ一

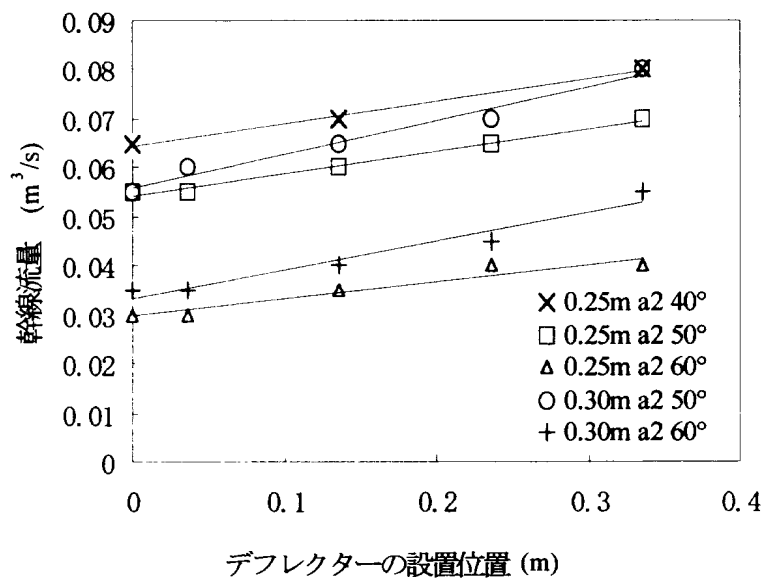

図 7: デフレクター位置と露出射流発生時の流量 
定化する傾向が見られる，すなわち，バースクリー ン型渓流取水工による取水量には限界值があるこ とが認められる。

いま, デフレクタ一の設置位置と露出射流発生時 の流下流量との関係をバー長 $0.25 \mathrm{~m}$ の時 $40^{\circ}, 50^{\circ}$, $60^{\circ}$, バ一長 $0.30 \mathrm{~m}$ の時 $50^{\circ}, 60^{\circ}$ についてグラフ化す ると図 7 のようになる。これより,デフレクターの 設置位置, すなわち, 水クッション水平長が長くな ればなるほど露出射流を発生させる流下流量は大 きくなり,露出射流が発生すると取水量はほぼ一定 化することを考えると, デフレクターの位置を後方 に設置する方が取水量は増加することが分かる。こ の傾向は, バーの取付角度が変化してもはぼ同じで ある. また, 図 7 中のバー長 $0.25 \mathrm{~m}$ と $0.30 \mathrm{~m}$ とを比 較すると,バ一長が長くなればなるほどこのような 傾向は顕著に現れ, バ一長が長いだけでも取水量が 增加することを考えると, バー長を長くし, デフレ クターの設置位置を後方にすれば, より多くの取水 量を得ることが可能となる.

\subsection{2 角落としによる取水量の変化}

次に, 水クッション内に角落しを設置する場合につ いて考察する, 角落し設置位置の違いによる流況の 変化を写真 4 と写真 5 に示す。この場合, 角落し位 置が，バーの末端部に近づくほど，すなわち，水ク ッションの水平長が短いほど取水量は増大傾向を 呈する.

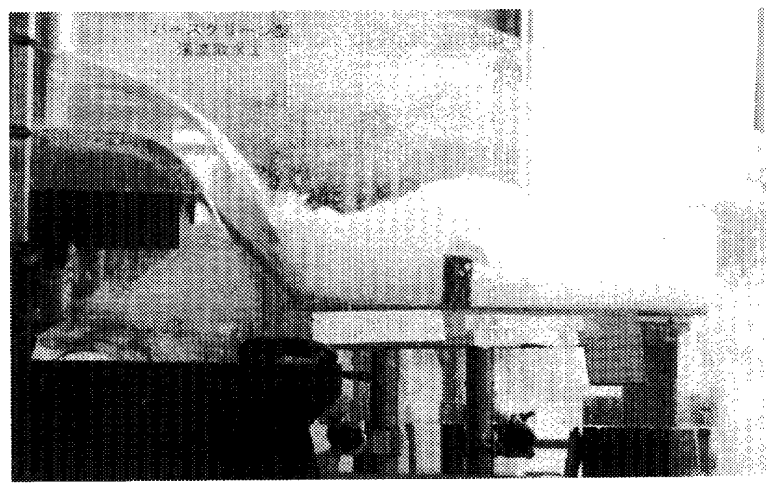

写真 4: 角落とし前方設置時の流況

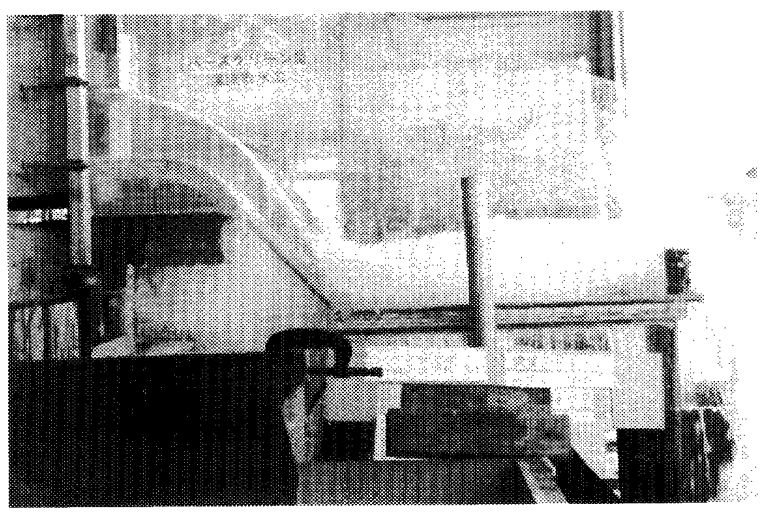

写真 5: 角落とし後方設置時の流況
すなわち, 写真 4 の場合, 角落しの設置位置がバ 一スクリーンに近いほど水流が角落しに衝突して 流況はローリング現象を呈し,水クッション内の水 位の上昇が見られ後方流入水が増加する. 一方, 写 真 5 の場合は, 角落しが後方にあるために, 水クッ ション内の水位上昇があまり見られず, 渓流取水工 による取水量の増加が得られない状況である.

これらの角落し設置位置の違いによる水クッシ ヨン内の水位変化を示すと図 8 のようになる. 実験 条件はバーの長さ $0.30 \mathrm{~m}$, 取付角度 $50^{\circ}$, 隙間幅 $0.02 \mathrm{~m}$ ，角落し高 $0.10 \mathrm{~m}$ の場合である.

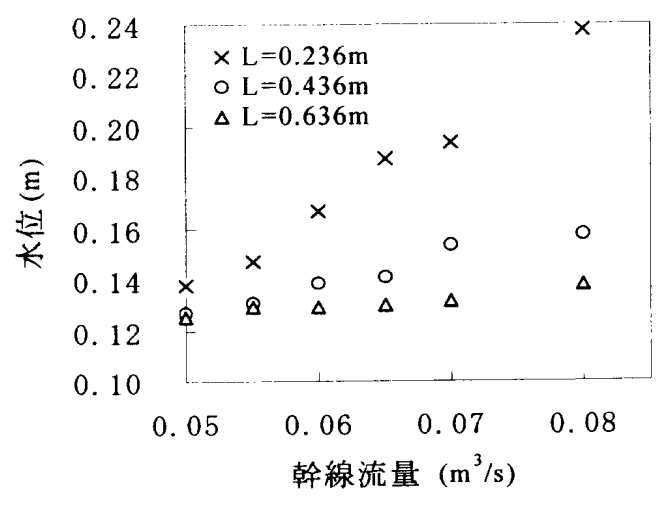

図 8: 水クッション内の水位変化

たとえば，角落しをバーの末端部から $0.236 \mathrm{~m} に$ 設置した場合, 幹線流量 $0.08 \mathrm{~m}^{3} / \mathrm{s}$ のとき, 水クッ ション内の水位は $0.24 \mathrm{~m}$ を呈した. また, 水平長を $0.636 \mathrm{~m}$ に設置した場合は約 $1 / 2$ の $0.13 \mathrm{~m}$ であった。 角落しの設置位置を $0.436 \mathrm{~m}$ と $0.636 \mathrm{~m}$ にすると, 水クッション底床部水平長が長くなるため, 水クッ ション内の水位は大幅に下り，取水量は減少すると 考えられる.

以上の実験から, 同じ垂直高の角落しとデフレク ターを設置した場合の取水状況を比べると, デフレ クターの方はバーの末端部から離れるほど取水量 は増加するが, 角落しの場合はバーの末端部に近づ くほど取水量は増加する傾向にある. また, デフレ クターを設置する場合, 流下流量がある量に達する と露出射流を発生し, 本来の, デフレクターの取水 量増大の効果がなくなる. 一方, 角落しの場合は流 下流量が増加しても露出射流は発生しにくいため, デフレクター設置の場合と比較すると取水量は多 くなると考えられる.

\section{3 バーの膘間幅の进いによる取水量の変化}

図 9 は, バ一の長さ $0.30 \mathrm{~m}$, 取付角度 $50^{\circ}$ のときの 開度の違いによる取水量の変化を示している. 本研 究では,バーの隙間幅(a)を $0.01 \mathrm{~m}$ から $0.02 \mathrm{~m}$ に変化

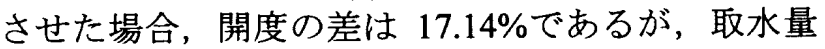
の差はあまりなく, 図 9 からも認められるように最 大でも $8 \%$ 程度の増加である. すなわち, バ一間隙 幅の大小は地形や流下土砂碩の量や大きさを考慮 しながら決定する必要がある. 


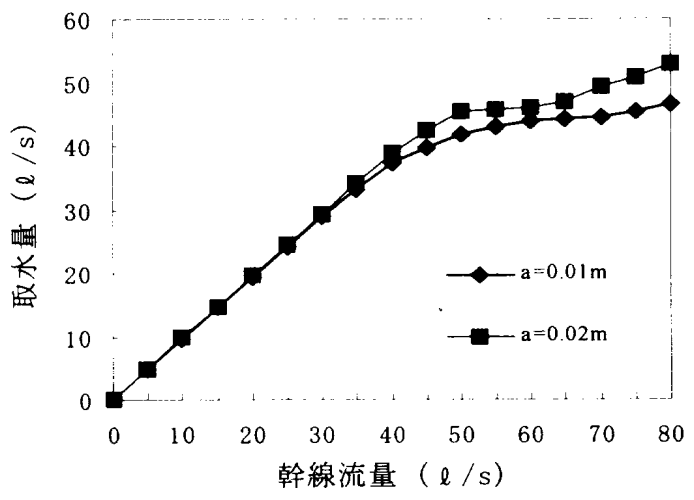

図 9: バーの隙間幅による取水量の変化

\section{5 まとめ}

本研究は, 砂防ダムと渓流取水工とを合体させた取 水と砂防の両面の役割を有する多目的な構造物の 開発を目的として，特に，取水面の構造について実 験的に検討したものである.

バースクリーン渓流取水工の取水量は主にバー の取付角度によって決定され，取付角度が小さいほ ど取水量は多くなるが，土砂磁や枯れ葉等によるバ 一スクリーンの目詰まりの問題が起こる.土砂磷の 流下に対するバーの強度を考えると, バーの取付角 度は $50^{\circ}$ 前後にするのが最良であると考える.
また, デフレクターと角落しの設置による取水量 の増水効果を比較した結果, デフレクターの方はバ 一の末端部から離れるほど, すなわち, 水クッショ ン底床部水平長が長くなるほど取水量は増大する。 しかし，角落しの方は，バーの末端部に近く設置す るほど取水量が増大することが確認された。この結 果, 砂防ダム方式の渓流取水工の場合, デフレクタ 一よりも角落しの方が効果的である.すなわち，砂 防ダムの限られた天端幅（1.5〜2.0m）には，角落 としを設置する方が多量の取水量を得ることがで き，土砂碩の流下を軽減することにもつながる．し かし, 角落しが, 土石流によって破壊された時には, 再び取り換え可能な構造にすることが必要である.

\section{引用文献}

[1] 公共事業チェック機構を実現する議員の会 (1997): アメリカはなぜダム開発をやめたのか, 筑地書館, pp.1-204.

[2] 秋吉康弘 - 張 興奇(1999) : 離島に扔ける雨水の高度 利用( II ), 雨水資源化システム学会誌，4(2), pp.2126.

[3] 塚本良則・ 小橋澄治 (1993): 新砂防工学, 朝倉書店, pp.73-89.

[4] 東 三郎 (1982): 低ダム群工法 一土砂害予防の理 論一, 文永堂出版, pp.368-373. 